The perception of being green: does it result in happy workers?

\section{Employee satisfaction and environmental reputation}

Companies around the world are investing in both reducing their negative environmental impacts and in communication efforts to improve their reputation for being green. Scholars, managers, and others have been trying to determine the effects of such investments. By Adam J. Sulkowski and Cassandra Walsh

B oth the investments of a company that are oriented toward actual operational changes and those oriented toward creating positive public images ultimately can contribute to the company's reputation for being green, or, in other words, having good perceived environmental performance.

The most intuitively obvious effects of having a positive green reputation are such benefits as overall company and product branding, improvement in market share, and stakeholder relations and access to capital. Less obvious are effects upon internal company functioning and employees.

A recent study found a causal connection between a company's reputation for being green and employee satisfaction (1). This article will discuss the major findings of this study and implications for the benefit of a mixed audience of academics, policy makers, and managers.

\section{Green reputation and employee satisfaction}

The authors tested if a company's green reputation leads to higher employee satisfaction. The authors also tested whether, in the same sample of companies, better financial performance leads to higher levels of employee satisfaction.

This article uses the terms „perceived environmental performance“ and „green reputation " to mean the reputation of a company for functioning in a way that results in comparatively less negative envi- ronmental impacts, or, in other words, better environmental performance. It is important to note that actual environmental performance of firms was not studied, but rather the perception of it.

Data on 113 companies was used for the study. These 113 companies belong to the Standard and Poor's 250 and therefore are all large and represent numerous industries. These companies were chosen because they annually report on their corporate responsibility efforts. The authors used this criterion because reporting on their responsibility efforts shows that these companies expend some effort in managing their reputations. Data regarding their reputation for environmental performance was obtained through a company reputation ranking service, Vanno. Vanno was also the source of data on relative employee satisfaction. Financial performance data was collected from the companies' public reports.

A regression analysis demonstrated, with 99.9 percent confidence, that there is a significant positive relationship between having a good reputation with regard to environmental performance and employee satisfaction. In contrast, no significant relationship between company financial performance and employee satisfaction was found.

\section{Employee satisfaction and financial performance}

To the best knowledge of the authors, the research described above was the first to establish a positive relationship between good perceived environmental performance and employee satisfaction, so this is perhaps the key contribution to scholarship of sustainability and management.

This finding is consistent with data concerning the motivations of companies for reporting on environmental performance. Both a 2005 and 2008 survey by KPMG found that „winning the war for talent", or improving the recruitment, retention, and motivation of employees, was a top driver of corporate reporting on efforts to be more responsible with regard to effects on societies, economies, and the environment.

The finding that employee satisfaction does not correlate in any way with their companies' financial performance is not surprising, inasmuch as firms often perform better financially when they lay-off or otherwise reduce remuneration and benefits to employees.

\section{Managing a company's reputation}

The implication of the study's key finding is that managing a company's reputation for good environmental performance is relevant to its management of human resources. Employers may find it easier to attract and retain and motivate future and current employees if the company is known for being green. Publicity of the company's efforts to become more environmentally sustainable - and its progress toward reducing its environmental footprint - should perhaps be a part of its human resources management strategy. While such communication can take many forms, the authors speculate that any such effort is a step in the right direction. The authors suggest, however, that using a respected standard for sustainability reporting, such as one of those of the Global Reporting Initiative, provides the best guidance for communicating about environmental performance in a way that is credible, clear, comparable, and comprehensive.

Since the completion of the study, the authors have been asked several clarifica- 
tion questions. The answers to these common questions actually may help in understanding the applicability and limitations and implications of the key finding.

- First, the authors are not proclaiming that profitability or other measures of financial performance do not matter. Neither are the authors declaring a moral judgment. The authors' suggestion, based on this study, is simply that communicating about an organization's environmental performance and its efforts to become more environmentally benign can yield benefits related to human resources.

- Second, it may bear repeating that actual environmental performance is not necessarily the key factor in creating happier employees, even though this may be proven to be true by another study. Neither is disciplined reporting on environmental performance necessarily the key driver of employee attitudes or perception, though this may also be proven to be true by another study. This study only investigated the power of having a reputation for good environmental performance to affect employee satisfaction. The key finding does suggest that efforts to manage environmental reputation have the effect of boosting employee happiness. The study does not provide a basis for speculation about other effects of managing environmental reputation.

- A third set of questions is related to the applicability of recommendations based on the key finding in other contexts. While the sample contained only large companies, the relationship between having a green reputation and having satisfied employees may also exist among medium and small companies. While the sample contained only companies that publish some information about their environmental, societal, and economic performance, the relationship may also exist among companies that fail to make any such efforts. Also, while the sample only contained for-profit entities, the key finding and its implications may be applicable in the context of charities, other non-profit organizations, international organizations, and government entities.

\section{Conclusion}

The amount of interest in the results of the study has been very encouraging. It is noteworthy that this research has been cited in news stories around the world. This is indicative of the increasingly intense and global sense of urgency that humanity must continue to evolve our institutions. The authors hope that their research continues to be a foundation for further dialogue, research, and action in the field of business and policy studies and the actual management of organizations.

\section{Annotation}

(1) The results of the study were published in the following article: Walsh, C. and Sulkowski, A.J.: A greener company makes for happier employees more so than does a more valuable one: a regression analysis of employee satisfaction, perceived environmental performance and firm financial value. In: Interdisciplinary Environmental Review 11, 4/2010, pp.274-282.

\section{AUTHORS + CONTACT}

Adam J. Sulkowski is an Assistant Professor of Business Law and Sustainability at the Charlton College of Business at University of Massachusetts Dartmouth.

Cassandra Walsh is a Human Resources Coordinator at EMC Corporation.

Adam J. Sulkowski, Assistant Professor of Business Law, Charlton College of Business, University of Massachusetts Dartmouth, 285 Old Westport Road, North Dartmouth, MA 02747. Internet: http://adamsulkowski.com/

\section{Besser statt mehr}

Was garantiert uns Wohlstand und sozialen Frieden? Wie ein Mantra kommt die Antwort aus Politik und Wirtschaft: Wachstum. Aber dürfen wir das angesichts der jüngsten Wirtschaftskrisen noch glauben? Der britische Ökonom Tim Jackson fordert rigoroses Umdenken und die Entwicklung einer neuen Wirtschaftsordnung, die auf einem anderen Wohlstandsbegriff beruht. Im Mittelpunkt seiner Überlegungen stehen eine nachhaltige Ökonomie und die Vision einer blühenden Gesellschaft innerhalb bestehender ökologischer Grenzen.

\section{T. Jackson}

Wohlstand ohne Wachstum

Leben und Wirtschaften in

einer endlichen Welt

240 Seiten, Hardcover mit

Schutzumschlag, 22,95 EUR

ISBN 978-3-86581-245-2

\section{II oekom}

Die guten Seiten der Zukunft

Erhältlich bei www.oekom.de kontakt@oekom.de

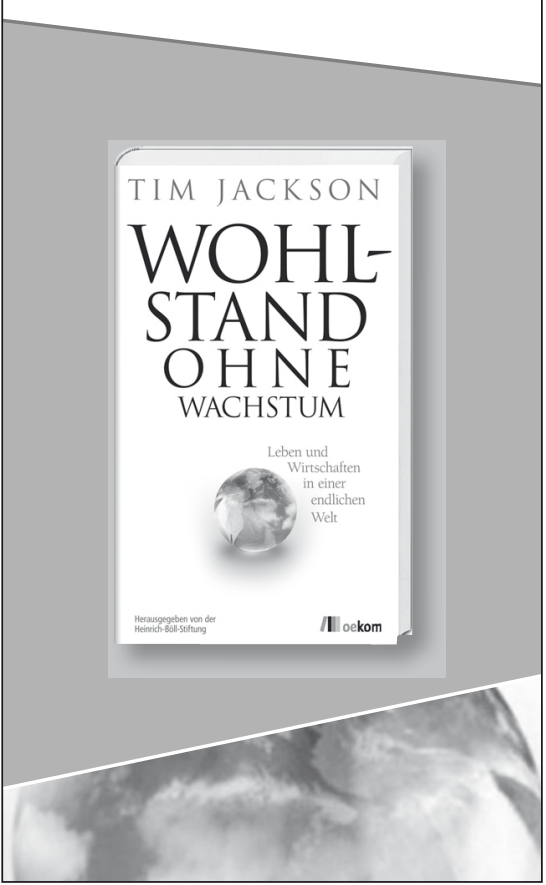




\section{Lizenzhinweis}

Die Beiträge in ÖkologischesWirtschaften werden unter der Creative-Commons-Lizenz "CC 4.0 Attribution Non-Commercial No Derivatives" veröffentlicht. Im Rahmen dieser Lizenz muss der Autor/Urheber stets genannt werden, das Werk darf nicht bearbeitet, abgewandelt oder in anderer Weise verändert und außerdem nicht kommerziell genutzt werden. Die digitale Version des Artikels bleibt für zwei Jahre Abonnent/innen vorbehalten und ist danach im Open Access verfügbar. 